\title{
Evaluation of Eucalyptus microcorys wood properties
}

\author{
Marta Cristina de Jesus Albuquerque Nogueira $\odot^{1} J u l i a n o ~ S o u z a ~ V a s c o n c e l o s\left({ }^{2}\right.$ Victor Almeida De \\ Araujo $\oplus^{3}$ André Luis Christoforo $\oplus^{4 *}$ Francisco Antonio Rocco Lahr $\oplus^{5}$
}

\footnotetext{
${ }^{1}$ Universidade Federal do Mato Grosso, Av. Fernando Corrêa da Costa, 2367, Boa Esperança, CEP: 78060-900, Cuiabá, MT, Brasil.

${ }^{2}$ Universidade Estadual Paulista Júlio de Mesquita Filho, Av. Universitária, 3780, Altos do Paraíso, CEP: 18610-034, Botucatu, SP, Brasil

${ }^{3}$ Pesquisador independente no LIGNO - Research Group, Universidade Estadual Paulista, R. Geraldo Alckmin, 519, CEP:18409-010, Vila Nossa Sra. de Fatima, Itapeva - SP, Brasil

${ }^{4}$ Universidade Federal de São Carlos, Rod. Washington Luiz, s/n, CEP: 13565-905, São Carlos, SP, Brasil

${ }^{5}$ Universidade de São Paulo, Av. Trabalhador São Carlense, 400, CEP: 13566-590, São Carlos , SP, Brasil
}

\section{Original Article \\ *Corresponding author:} christoforoal@yahoo.com.br

Keywords:

Tallowwood

Density

Moisture content

Wood resistance

Palavras-chave:

Eucalipto de sebo

Densidade

Teor de umidade

Resistência da madeira

Received in

$2020 / 07 / 28$

Accepted on

2020/08/07

Published in: 2021/01/12

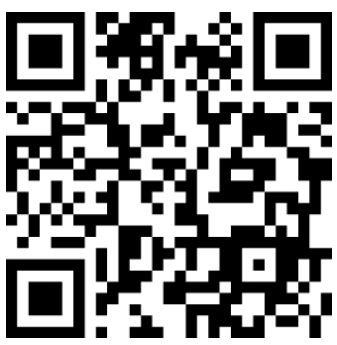

DOI: http://dx.doi.org/ 10.34062/afs.v7i4.10882

\section{(cc) BY}

ABSTRACT: Eucalypt varieties have been identified as multipurpose materials. With origins in the Oceania region, this genus has been applied for purposes such as pulp and paper, bioenergy, civil construction, and furniture. Very suitable as firewood and charcoal, Eucalyptus microcorys would have good potentialities as structural solutions for construction. But, this wood species is not easily found as building parts in the Brazilian market. This paper aimed to develop a broad evaluation of this species to highlight their features for the utilization as structural lumber. Based on the Brazilian standard document ABNT NBR 7190 (1997), sixteen properties were evaluated at two moisture contents conditions, green and dried points. About 966 repeats were realized in these tests. Nine properties showed influences with the moisture reduction as well as perceptible increases in their resistances: static bending, parallel and perpendicular compressions, and parallel tensile in the modulus of rupture; perpendicular compression and parallel tensile in the modulus of elasticity; and shear stress and hardness properties in parallel and perpendicular directions. Eucalyptus microcorys wood reached good resistance properties, justifying its potentiality for structural uses.

\section{Avaliação das propriedades da madeira de Eucalyptus microcorys nos teores de umidade de $30 \%$ e $12 \%$}

RESUMO: As variedades de eucalipto têm sido identificadas como matériasprimas multifuncionais. Com origens na região da Oceania, esse gênero tem sido aplicado para propostas como papel e celulose, bioenergia, construção civil e movelaria. Muito adequado como lenha e carvão, o Eucalyptus microcorys teria boas potencialidades como soluções estruturais para a construção civil. Porém, essa espécie de madeira não é facilmente encontrada como elementos construtivos no mercado brasileiro. Sendo assim, esse artigo teve como objetivo desenvolver uma ampla avaliação dessa espécie para destacar as suas características para a utilização na forma de madeira serrada estrutural. Com base no documento normativo brasileiro ABNT NBR 7190 (1997), dezesseis propriedades foram avaliadas em duas condições de teor de umidade, pontos verde e seco. Ao redor de 966 repetições foram realizadas nesses testes. Nove propriedades mostraram influências com a redução de umidade bem como aumentos perceptíveis em suas resistências: flexão estática, compressões perpendiculares e paralelas e tração paralela no módulo de ruptura; compressão perpendicular e tração paralela no módulo de elasticidade; e as propriedades de tensão de cisalhamento e dureza nas direções paralela e perpendicular. A madeira do Eucalyptus microcorys alcançou boas propriedades de resistência, justificando a sua potencialidade para usos estruturais. 


\section{Introduction}

Tallowwood is among the six most popular hardwoods in Australia (Krilov 1986), and its origin is related to Myrtaceae family, particularly, in those dicotyledonous woody plants (Govaerts et al. 2008). Being an important commercial wood obtained from a clearly defined botanical species, tallowwood is the trade name of the Eucalyptus microcorys F. Muell (Costa and Rudman 1957). Its origin is widely distributed in Australian regions of northern coastal New South Wales and south-eastern Queensland, between the coast and the higher altitudes (Hills and Brown 1931; Boland et al. 2006). Tallowwood efficiently grows in latitudes between $25^{\circ}$ to $32^{\circ} \mathrm{S}$, especially in wet weather, with hot summer and cold winter, and annual rainfall from 800 to 1600 millimeters, living both in good soils and in poor ones (Hills and Brown 1931). This occurrence is justified by its presence in tall open forests commonly on rainforest fringes, associated with at least six other Eucalyptus species (Boland et al. 2006). Since 1980s, tallowwood has been found in Brazil, particularly, in the states of São Paulo, Minas Gerais, and Rio Grande do Sul (Jankowsky and Aguiar 1983; Brito et al. 1983; Pereira et al. 2000; Shimizu and Carvalho 2000; Martins et al. 2013).

Microcorys is a medium-sized to very tall tree with 35 to 60 meters tall, and occasionally exceeding $70 \mathrm{~m}$ in height and $3 \mathrm{~m}$ in diameter at breast height (Goes 1960; Boland et al. 2006). A large tree has a fibrous, persistent and soft bark, as well as a dense crown of rather small leaves (Crawford 2011).

Tallowwood trees presents fast growth and a wood production value (Sun and Dickinson, 1996). Its tree shape and timber are showed in the Figure 1.
From ten-year trees planted at $3 \times 2$ meterspacing in Uberaba, Brazil, a study about Eucalyptus microcorys showed specimens with $15.40 \pm 0.80$ meter-tall, $0.10 \pm 0.01 \mathrm{~m}^{3}$ in commercial volumes with bark, and $0.64 \pm 0.01 \mathrm{~g} / \mathrm{cm}^{3}$ in basic density (Pereira et al. 2000).

Eucalyptus microcorys timber is light colored predominately yellowish brown, and is hard and heavy with a bulk density ranging from 0.90 to 1.10 $\mathrm{g} / \mathrm{cm}^{3}$ (Hills and Brown 1931; Goes 1960). This fibrous wood has a greasy nature, making gluing complex (Boland et al. 2006).

Tallowwood has a smoldering combustion (Hills and Brown, 1931), and this species is useful as biomass energy due to high density, whose fact has reinforced its utilization as firewood and charcoal (Golfari et al. 1978; Brito et al. 1983; Shimizu and Carvalho 2000). This species is not suitable for pulp and paper (Hills and Brown, 1931). Its wood has easy workability and low susceptibility to cracking by nailing, which constitutes in one of the finest woods from the Eucalyptus genus (Goes 1960; Marchesan et al. 2005). It has great quality for the production of sawn timber, and is suitable for light and heavy construction, rural applications in posts and poles, railway sleepers, fences, floors and decks (Hills and Brown 1931; Golfari et al. 1978; Shimizu and Carvalho 2000; Boland et al. 2006).

Several studies have been prepared to explore different uses for tallowwood in civil construction such as plywood boards (Jankowsky and Aguiar 1983; Bortoletto Jr. 2003), solid timber (Tomazello Filho 1985; Marchesan et al. 2005), and flooring (Martins et al. 2013).

(A)


Figure 1. Eucalyptus microcorys: (A) tree and (B) timber surface. Sources: (A) Diversity Native Seeds (2013) and (B) Australian Architectural Hardwoods (2016). 
Even in this scenario, microcorys wood is not commonly applied for construction in Brazil, while this species is unusual in the domestic stores of home improvement. Then, this study aimed to mitigate this great unfamiliarity by a broad evaluation of physical and mechanical properties and reinforce the potential of Eucalyptus microcorys for structural purposes.

\section{Material and Methods}

Eucalyptus microcorys trees were collected from different cities in the São Paulo State: Rio Claro, Itirapina and Pradópolis. Different wooden logs and beam samples with varied ages were used to establish a randomized characterization (Table 1).

From structural attributes prescribed by the ABNT NBR 7190 (1997) standard document, two physical properties and fourteen mechanical tests were performed to evaluate this selected wood.

Volumetric mass density and bulk density were those physical tests. The mechanical properties included five moduli of rupture (perpendicular and parallel compressions, perpendicular and parallel tensiles, and static bending), four moduli of elasticity (perpendicular and parallel compressions, parallel tensile, and static bending), and five other strength properties (shear stress, cleavage, parallel hardness, perpendicular hardness, and toughness). Different moisture content conditions (green point at $30 \%$ and standard point at 12\%) specified by ABNT NBR 7190 (1997) were considered for wood samples to establish comparative results. These mean values were analyzed with t-test at 5\% level of significance using Microsoft Excel 2016.

\section{Results and Discussion}

Results were organized with accordance to physical testing (Table 2) and mechanical tests (Tables 3 to 5) for modulus of rupture, modulus of elasticity, and other strength properties.

By means of moisture reduction from green point at $30 \%$ to dried point at $12 \%$, a decrease was confirmed for the physical property of bulk density (Table 2), specifically, in the order of $0.18 \mathrm{~g} / \mathrm{cm}^{3}$. From t-test, the statistical analysis revealed an influence of moisture content reduction in the bulk density (P-value <0.05).

Table 1. Details of Eucalyptus microcorys wood samples.

\begin{tabular}{lllll}
\hline Log Amount & Beam Amount & Age & Diameter $(\mathrm{m})$ & Region in São Paulo State \\
\hline 1 & 2 & 34 & 0.27 & Rio Claro \\
2 & 2 & 34 & 0.29 & Rio Claro \\
3 & 2 & 34 & 0.25 & Rio Claro \\
4 & 2 & 34 & 0.23 & Rio Claro \\
5 & 2 & 34 & 0.24 & Rio Claro \\
6 & 6 & 15 & 0.27 & Itirapina \\
7 & 6 & 15 & 0.27 & Itirapina \\
8 & 6 & 15 & 0.31 & Pradópolis \\
9 & 6 & 15 & 0.32 & Pradópolis \\
\hline
\end{tabular}

Table 2. Results for wood density of Eucalyptus microcorys.

\begin{tabular}{llllll}
\hline Characteristic & $\mathrm{MC}(\%)$ & $\mathrm{n}$ & $\mathrm{M}$ & $\mathrm{sd}$ & $\mathrm{P}$-value \\
\hline Bulk Density $\left(\mathrm{g} / \mathrm{cm}^{3}\right)$ & 30 & 31 & 1.11 & 0.09 & 0.0000 \\
\hline Volumetric Mass Density $\left(\mathrm{g} / \mathrm{cm}^{3}\right)$ & 12 & 30 & 0.93 & 0.10 & - \\
\hline
\end{tabular}

MC: moisture content; $\mathrm{n}$ : repeat; M: property means; sd: standard deviation

According to Australian Standard AS 1720.2 (2006) for timber structures, the average bulk density for Eucalyptus microcorys wood is $1.20 \mathrm{~g} / \mathrm{cm}^{3}$ in green condition and $1.00 \mathrm{~g} / \mathrm{cm}^{3}$ in dried state. For felled trees at young ages, 10 years for example, this species can present volumetric mass density values varying from 0.50 to $0.70 \mathrm{~g} / \mathrm{cm}^{3}$ as suggested by Brito et al. (1983) and Tomazello et al. (1985), whereas wood samples from older tallowwood trees usually reach variations in this property in the order of 0.70 to $1.00 \mathrm{~g} / \mathrm{cm}^{3}$ as cited by Martins et al. (2013) and Britton Timber (2015). Physical properties of tested samples (Table 2) were similar to literature.
As suggested by Melo et al. (1992) assortment, this studied species would be classified as a hardwood.

In modulus of rupture (Table 3 ), there were increases in the parallel compression $(\mathrm{a}+9.9 \mathrm{MPa}$ difference in the studied condition), perpendicular compression (+3.1 MPa), parallel tensile $(+28.6$ $\mathrm{MPa})$, perpendicular tensile $(+0.4 \mathrm{MPa})$, and static bending $(+11.7 \mathrm{MPa})$ with the moisture decrease from 30 to $12 \%$. The t-test indicated that the perpendicular tensile did not present statistical difference in the mean values with the moisture content reduction, as observed in the other four rupture properties. 
In static bending (Table 3), tallowwood had a worst rupture value than dunnii (116.97 $\mathrm{MPa})$ and tereticornis (132.71 MPa) eucalypt woods tested by Carvalho et al. (2019).

With the moisture decrease for the modulus of elasticity (Table 4), three respective properties were increased $(+3628.30 \mathrm{MPa}$ for parallel tensile, $+286.80 \mathrm{MPa}$ for perpendicular compression, and $+1144.60 \mathrm{MPa}$ for parallel compression), and only the static bending was decreased $(-47.10 \mathrm{MPa})$.

The t-test analysis also showed that parallel tensile and perpendicular compression properties were influenced in their means by the moisture content variation/decrease/change ( $\mathrm{P}$-value $<0.05)$. Static bending of this study (Table 4) was practically the same value prescribed by Britton Timber (2015). This property was greater than dunnii (12237.40 $\mathrm{MPa}$ ) and tereticornis (16469.20 $\mathrm{MPa})$ species in study by Carvalho et al. (2019).

Tangential toughness demonstrated a slight decrease $(-0.20$ N.m) between initial and final points (green and dried) (Table 5).

Other strength properties were increased, for example, shear stress (4.80 MPa), parallel hardness $(2.98 \mathrm{kN})$, perpendicular hardness $(1.99 \mathrm{kN})$, and tangential cleavage $(0.12 \mathrm{MPa})$ (Table 5$)$.

Table 3. Results for modulus of rupture of Eucalyptus microcorys.

\begin{tabular}{llllll}
\hline Characteristic & $\mathrm{MC}(\%)$ & $\mathrm{n}$ & $\mathrm{M}$ & $\mathrm{sd}$ & $\mathrm{P}$-value \\
\hline \multirow{2}{*}{ Parallel Compression (MPa) } & 30 & 32 & 45.00 & 7.80 & 0.0001 \\
\hline \multirow{2}{*}{ Perpendicular Compression (MPa) } & 12 & 30 & 54.90 & 10.10 & \multirow{2}{*}{0.0005} \\
\hline \multirow{2}{*}{ Parallel Tensile (MPa) } & 30 & 32 & 4.60 & 1.00 & 0.0113 \\
\hline \multirow{2}{*}{ Perpendicular Tensile (MPa) } & 12 & 29 & 7.70 & 4.20 & 33.40 \\
\hline \multirow{2}{*}{ Static Bending (MPa) } & 30 & 31 & 90.00 & 49.70 & \multirow{2}{*}{0.3500} \\
\hline
\end{tabular}

MC: moisture content; $n$ : repeat; M: property means; sd: standard deviation

Table 4. Results for modulus of elasticity of Eucalyptus microcorys.

\begin{tabular}{llllll}
\hline Characteristic & $\mathrm{MC}(\%)$ & $\mathrm{n}$ & $\mathrm{M}$ & $\mathrm{sd}$ & P-value \\
\hline \multirow{2}{*}{ Parallel Compression (MPa) } & 30 & 32 & 16293.00 & 4770.70 & \multirow{2}{*}{0.3812} \\
\hline \multirow{2}{*}{ Perpendicular Compression (MPa) } & 12 & 30 & 17437.60 & 5398.30 & \multirow{2}{*}{0.0011} \\
\hline \multirow{2}{*}{ Parallel Tensile (MPa) } & 30 & 32 & 463.60 & 97.20 & 0.0121 \\
\hline \multirow{2}{*}{ Static Bending (MPa) } & 12 & 28 & 750.40 & 408.80 & 0.9684 \\
\hline
\end{tabular}

MC: moisture content; $\mathrm{n}$ : repeat; $\mathrm{M}$ : property means; sd: standard deviation

Table 5. Results for other strength properties of Eucalyptus microcorys.

\begin{tabular}{llllll}
\hline Characteristic & $\mathrm{MC}(\%)$ & $\mathrm{n}$ & $\mathrm{M}$ & $\mathrm{sd}$ & $\mathrm{P}$-value \\
\hline \multirow{2}{*}{ Shear Stress (MPa) } & 30 & 32 & 12.20 & 2.50 & 0.0000 \\
\hline \multirow{2}{*}{ Tangential Cleavage (MPa) } & 12 & 30 & 17.00 & 2.60 & \multirow{2}{*}{0.0578} \\
\hline \multirow{2}{*}{ Perpendicular Hardness (kN) } & 30 & 31 & 0.76 & 0.24 & 0.0740 \\
\hline \multirow{2}{*}{ Parallel Hardness (kN) } & 12 & 29 & 0.88 & 0.24 & 1.73 \\
\hline \multirow{2}{*}{ Tangential Toughness (N.m) } & 30 & 32 & 7.17 & 5.67 & \multirow{2}{*}{0.0000} \\
\hline
\end{tabular}

MC: moisture content; $\mathrm{n}$ : repeat; M: property means; sd: standard deviation 
In t-test, three properties (parallel hardness, perpendicular hardness, and shear stress) showed influences in their means with this moisture content changes (P-value < 0.05), while other two properties were not influenced in this same condition (Table 5).

Shear stress values at $30 \%$ and $12 \%$ moisture content were visibly greater than the property value (10.30 MPa) cited by the ABNT NBR 7190 (1997).

Due to relevant properties in flooring uses, Martins et al. (2013) also suggested the application of tallowwood, whereas its performance was similar to cloeziana variety and better than maculata species concerning anisotropy coefficients, and volumetric, tangential and radial shrinkages.

Eucalyptus microcorys was mechanically superior to some eucalypts evaluated in other wood characterization studies, for example, alba (Nogueira et al., 2019b), camaldulensis (Nogueira et al., 2018c), grandis (Lahr et al., 2018), maidenii (Nogueira et al., 2018b), saligna (Nogueira et al., 2019a), umbra (Nogueira et al., 2018a), and urophylla (Lahr et al., 2017). Still, this wood species reached performances similar to tereticornis variety studied by Nogueira et al., (2020). These efficient values regarding the mechanical properties evinced that Eucalyptus microcorys wood species has decent resistance for structural parts (Tables 3 to 5), being suitable for construction applicability. Still, its use in solid timber products should be intensified by the different advantages of eucalypts, since Eleotério et al. (2015) have attributed this genus to a series of viabilities related to performances in processing and with their physical and mechanical properties. Also, other reason would be based on Müller et al. (2017), which also emphasized that the Eucalyptus genus is a leading material source to replace Amazon woods, since De Araujo et al. (2020) claimed an intense use of native lumber in traditional timber-based houses in Brazil.

\section{Conclusions}

As expected, bulk density was reduced with water loss, and volumetric mass density marked the Eucalyptus microcorys among the hardwoods.

While twelve mechanical properties of those Eucalyptus microcorys wood samples were clearly increased with the moisture content reduction from 30 to $12 \%$, only static bending in the modulus of elasticity and tangential toughness suffered slight decreases in this condition.

In the statistical analysis, nine evaluated properties suffered an influence with the moisture content reduction (static bending, parallel tensile, and parallel and perpendicular compressions in the modulus of rupture; perpendicular compression and parallel tensile in the modulus of elasticity; shear stress, perpendicular and parallel hardness values), whereas five properties did not reveal any influence in this condition. Such properties also presented a perceptible increasing in their studied resistances.
Compared to other eucalypt woods, tallowwood was mechanically efficient in many resistance properties, being a viable hardwood alternative for construction.

\section{References \\ ABNT (1997) NBR 7190 - Projeto de estruturas de madeira. Rio de Janeiro: ABNT.}

Australian Architectural Hardwoods (2016) Tallow wood. http://www.aahardwoods.com.au/timberspecies/tallowwood.

Australian Standard (2006) AS 1720.2 - Australian standard timber structures part 2: timber properties. Sydney: AS. pp.1-19.

Boland DJ, Brooker MIH, Chippendale GM, Hall N, Hyland BPM, Johnston RD, Kleinig DA, McDonald MW, Turner JD (2006) Forest trees of Australia. 5 ed., Collingwood: Csiro Publishing.

Bortoletto Jr. G (2003) Produção de compensados com 11 espécies do gênero Eucalyptus, avaliação das suas propriedades físico-mecânicas e indicações para utilização. Scientia Forestalis (63):65-78.

Brito JO, Barrichelo LEG, Seixas F, Migliorini AJ, Muramoto MC (1983) Análise da produção energética e de carvão vegetal de espécies de eucalipto. IPEF (23):53-56.

Britton Timbers (2015) Tallowwood: Eucalyptus microcorys. Prestons: Britton Timbers. pp.1-1.

Carvalho DE, Rocha MP, Klitzke RJ, Cademartori PHG, Juizo CGF, Martins APM (2019) Resistência e rigidez da madeira de espécies florestais submetidas a campo de apodrecimento. Advances in Forestry Science, 6(1):535-540.

Crawford P (Ed.) (2011) Tree identification manual: for the north-east Darling Downs regions. Oakey: North East Downs Landcare Group. pp.1-91.

Costa EWB, Rudman P (1957) The causes of natural durability in timber I. the role of toxic extractives in the resistance of tallowwood (Eucalyptus microcorys F. Muell.) to decay. Australian Journal of Biological Sciences 11(1):45-57.

De Araujo V, Vasconcelos J, Cortez-Barbosa J, Morales E, Christoforo A, Gava M, Lahr F, Garcia J (2020) Wood consumption and fixations of carbon dioxide and carbon from timber housing techniques: a Brazilian panorama. Energy \& Buildings 216:1-14.

Diversity Native Seeds (2013) Eucalyptus microcorys. diversitynativeseeds.com.au/specieslist-by-image/eucalyptus-microcorys-tallowwood. 
Eleotério JR, Reichert D, Hornburg KF, Meneguelli I (2015) Massa específica e retratibilidade da madeira de seis espécies de eucalipto cultivadas no litoral de Santa Catarina. Floresta 45(2):329-336.

Goes ESR (1960) Os eucaliptos em Portugal: identificação e monografia de 90 espécies. Lisboa: Secretaria de Estado da Agricultura. v. 1, pp.1-298.

Golfari L, Caser R, Moura VPG (1978) Zoneamento ecológico esquemático para reflorestamento no Brasil (2a. aproximação). Série técnica 11. Belo Horizonte: Prodepef. pp.1-66.

Govaerts R, Sobral M, Ashton P, Barrie F, Holst BK, Landrum LR, Matsumoto K, Mazine FF, Nic Lughadha E, Proença C, Soares-Silva LH, Wilson PG, Lucas EJ (2008) World checklist of Myrtaceae. Richmond: Kew Publishing/Royal Botanic Gardens.

Hills WE, Brown AG (1931) Eucalyptus for wood production. Melbourne: Csiro Publishing. pp.1-402.

Jankowsky IP, Aguiar OJR (1983) Manufatura de painéis compensados com Eucalyptus: caracterização de diversas espécies. Floresta 14(1): 46-53.

Krilov A (1986) Corrosion and wear of sawblade steels. Wood Science \& Technology 20(4):361-368.

Lahr FAR, Nogueira MCJA, De Araujo VA, Vasconcelos JS, Christoforo AL (2018) Wood utilization of Eucalyptus grandis in structural elements: densities and mechanical properties. Engenharia Agrícola 38:642-647.

Lahr FAR, Nogueira MCJA, De Araujo VA, Vasconcelos JS, Christoforo AL (2017) Physical mechanical characterization of Eucalyptus urophylla wood. Engenharia Agrícola 37(5):900-906.

Marchesan R, Mattos PP, Shimizu JY (2005) Caracterização física, química e anatômica da madeira de Eucalyptus microcorys F. Muell. n. 133. Colombo: Embrapa Florestas. pp.1-5.

Martins M, Silva JRM, Lima JT, Gonçalves MTT, Filipe AP (2013) Simulação em uso dos pisos de madeira de Eucalyptus sp e Corymbia maculata. Cerne 19(1):151-156.

Melo JE, Coradin VTR, Mendes JC (1992) Classes de densidade de madeira para a Amazônia brasileira. Silvicultura 12(42): 695-699.

Müller BV, Rocha MP, Klitzke RJ, Silva JRM, Cunha AB (2017) Produção de madeira serrada com cinco espécies de eucalipto resistentes à geada. Advances in Forestry Science, 4(4):195-201.
Nogueira MCJA, Almeida DH, De Araujo VA, Vasconcelos JS, Christoforo AL, Almeida TH, Lahr FAR (2019a) Physical and mechanical properties of Eucalyptus saligna wood for timber structures. Ambiente Construído 19(2):233-239.

Nogueira MCJA, Almeida DH, Vasconcelos JS, Almeida TH, De Araujo VA, Christoforo AL, Lahr FAR (2018a) Properties of Eucalyptus umbra wood for timber structures. International Journal of Materials Engineering 8(1):12-15.

Nogueira MCJA, De Araujo VA, Vasconcelos JS, Christoforo AL, Lahr FAR (2020) Sixteen properties of Eucalyptus tereticornis wood for structural uses. Bioscience Journal 36:449-457.

Nogueira MCJA, De Araujo VA, Vasconcelos JS, Cruz JN, Vasconcelos JCS, Prataviera F, Christoforo AL, Lahr FAR (2018b) Characterization of Eucalyptus maidenii timber for structural application: physical and mechanical properties at two moisture conditions. South-east European Forestry 9(2):1-6.

Nogueira MCJA, De Araujo VA, Vasconcelos JS, Gutiérrez-Aguilar CM, Cruz JN, Vasconcelos JCS, Prataviera F, Christoforo AL, Lahr FAR (2018c) Caracterización físico-mecánica de la madera de Eucalyptus camaldulensis para uso estructural proveniente de Restinga, Brasil. Revista Forestal de Peru 33(1):52-62.

Nogueira MCJA, De Araujo VA, Vasconcelos JS, Prataviera F, Vasconcelos JCS, Cruz JN, Christoforo AL, Lahr FAR (2019b) Propriedades físicomecânicas da madeira de Eucalyptus alba para construção civil. Ciência da Madeira 10(1):71-77.

Pereira JCD, Sturion JA, Higa AR, Higa RCV, Shimizu JY (2000) Características da madeira de algumas espécies de eucalipto plantadas no Brasil. Colombo: Embrapa Florestas. pp.1-113.

Shimizu JY, Carvalho PER (2000) Primeira aproximação na indicação de eucaliptos para produção de madeira na região de Quaraí, RS. Boletim de Pesquisa Florestal (40):101-110.

Sun D, Dickinson GR (1996) Suitability of Eucalyptus grandis and E. microcorys as windbreak species in tropical northern Australia. Journal of Tropical Forest Science 8(4):532-541.

Tomazello Filho M (1985) Variação radial da densidade básica e da estrutura anatômica da madeira do Eucalyptus gummifera, E. microcorys e E. pilularis. IPEF (30):45-54. 